was determined enzymatically as described ${ }^{5}$. Distillation of 1a from water was effected under reduced pressure and afforded pure succinic semialdehyde with physical properties in agreement with those reported in the literature ${ }^{3}$. The aqueous solution of 1a could also be liophylized and almost pure 1a could be easily recovered.

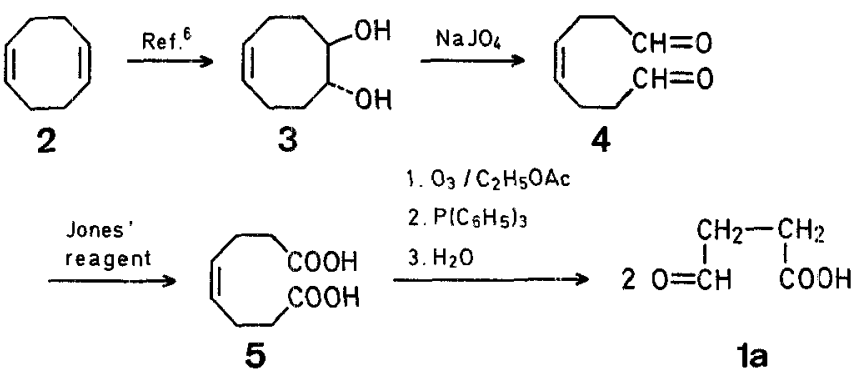

Treatment of 12 with an ethereal solution of diazomethane quantitatively afforded methyl 4-oxobutanoate, which could in turn be characterized as its 2,4-dinitrophenylhydrazone.

\section{A Convenient Synthesis of 4-Oxobutanoic Acid (Succinic Semialdehyde) from 1,5-Cyclooctadiene}

\section{Ada Manzocchl, Franca Astori, Enzo Santaniello*}

Istituto di Chimica, Facoltà di Medicina, Università di Milano, Via Saldini 50, I-20133 Milano, Italy

Succinic semialdehyde (4-oxobutanoic acid; 1a) is formed from 4-aminobutanoic acid (GABA) by transamination in the brain and in microorganisms and is therefore of relevance in neurochemistry' and in pharmacology ${ }^{2}$. The oxoacid $1 \mathbf{a}$ is rather unstable, since it easily polymerizes to the corresponding trioxane and is in equilibrium with the cyclic form of 5-hydroxy-4,5-dihydro-2(3H)-furanone (1b) ${ }^{3}$. The equilibrium can be completely shifted to the lactone $\mathbf{1 b}$ form in water at room temperature, although a hydrate structure cannot be excluded $^{4}$.

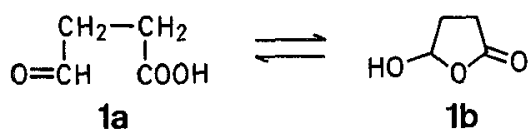

Recently, Wermuth has effected a synthesis in which aqueous hydrolysis of $\gamma$-ethoxybutyrolactone, in turn prepared from diethyl succinate, furnishes good yields of succinic semialdehyde (1a) ${ }^{3}$. We also have described an easy synthesis of $\mathbf{1 a}$, suitable for biochemical preparations ${ }^{5}$. Generally, the major byproduct of reductive ozonolysis, formaldehyde, was removed under a stream of nitrogen. However, in some cases formaldehyde was not completely eliminated from the aqueous solution of $1 \mathrm{a}$ and, although these aqueous solutions could be stored for several months at $-20^{\circ} \mathrm{C}$ without appreciable changes of concentration, and the presence of formaldehyde did not interfere with enzymatic determinations of 1a, a synthesis with no contamination of by-products seemed desirable.

We reasoned that ozonolysis of 4-octene-1,8-dioic acid (5) and reduction of the formed ozonide should afford 1a as the sole product. Therefore 5 was prepared in 35\% yield from commercially available and inexpensive cis,cis-1,5-cyclooctadiene (2) as shown below ${ }^{6,7}$. The diacid 5 was ozonized in ethyl acetate at $-78^{\circ} \mathrm{C}$. Treatment of the ozonide with a solution of triphenylphosphine in ethyl acetate at $-78^{\circ} \mathrm{C}$, followed by extraction with water, afforded an aqueous solution of $1 \mathrm{a}$ in $70 \%$ yield from 5 . The 2,4 -dinitrophenylhydrazone of la was obtained quantitatively and the concentration of 1a When 1a was treated with gaseous hydrogen chloride in excess ethanol, a mixture of $\gamma$-ethoxybutyrolactone and ethyl 4,4-diethoxybutanoate was formed, as established by ${ }^{1} \mathrm{H}$ N.M.R. analysis of the reaction mixture.

In conclusion, the easy synthesis of 1a outlined above should furnish an additional example of the versatility of the ozonolysis reaction. A suitable functionalized alkene, in fact, could be the best starting material for the preparation of sensitive molecules such as $1 a^{8}$.

\section{4-Octene-1,8-dial (4):}

trans-1,8-Dihydroxy-cyclooct-4-ene $[3 ; 5.86 \mathrm{~g}, 0.041 \mathrm{~mol}$; obtained from cis,cis-1,5-cyclooctadiene (2) according to Ref. $\left.{ }^{6}\right]$ is oxidized with sodium metaperiodate $(10.62 \mathrm{~g}, 0.046 \mathrm{~mol})$ following the procedure of Ref.' to give the dial 4; yield: $5.6 \mathrm{~g}$, which is used without further purification.

${ }^{1}$ H-N.M.R. $\left(\mathrm{CDCl}_{3}\right) ; \delta=2.5(\mathrm{~m}, 8 \mathrm{H}) ; 5.5(\mathrm{~m}, 2 \mathrm{H}) ; 10.0 \mathrm{ppm}(\mathrm{s}, 2 \mathrm{H})$.

(Z)-4-Octene-1,8-dioic Acid (5):

Crude dial $4(5.6 \mathrm{~g})$ is dissolved in acetone (distilled over potassium permanganate, $165 \mathrm{ml}$ ) and, after cooling at $-10^{\circ} \mathrm{C}$, Jones' reagent is added dropwise until a reddish colour persisted $(\sim 21 \mathrm{ml})$. Addition of 2-propanol $(1 \mathrm{ml})$ destroys excess of oxidant and the green mixture is filtered through Celite. After evaporation of the solvents, the residue is dissolved in ether $(60 \mathrm{ml})$, washed with water $(10 \mathrm{ml})$, and then extracted with saturated sodium hydrogen carbonate solution $(3 \times 10$ $\mathrm{ml})$. This solution is washed with ether $(10 \mathrm{ml})$, acidified with 4 normal hydrochloric acid $(10 \mathrm{ml})$, and extracted with ether $(3 \times 15 \mathrm{ml})$. After drying with sodium sulfate and evaporation of the solvent, the diacid

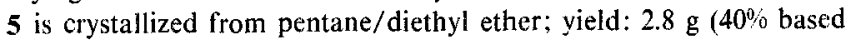
on 3); m.p. $96-98^{\circ} \mathrm{C}\left(\operatorname{Re}{ }^{7}\right.$, m.p. $\left.97-98^{\circ} \mathrm{C}\right)$.

$\begin{array}{llrr}\mathrm{C}_{8} \mathrm{H}_{12} \mathrm{O}_{4} & \text { calc. } & \mathrm{C} 55.80 & \mathrm{H} 7.03 \\ (172.2) & \text { found } & 55.95 & 7.10\end{array}$

I.R. (Nujol): $v=1740,1650 \mathrm{~cm}^{-1}$.

'H-N.M.R. $\left(\mathrm{CDCl}_{3}\right): \delta=2.5(\mathrm{~m}, 8 \mathrm{H}) ; 5.45(\mathrm{~m}, 2 \mathrm{H}) ; 10.90 \mathrm{ppm}(\mathrm{s}$, $2 \mathrm{H})$.

4-Oxobutanoic Acid (1a):

Ozone-enriched oxygen $(\sim 5 \%$ enrichment) is passed through a solution of the diacid $5(0.86 \mathrm{~g}, 0.005 \mathrm{~mol})$ in ethyl acetate $(20 \mathrm{ml})$ at $-78^{\circ} \mathrm{C}(15 \mathrm{~min})$. Excess of ozone is removec under a stream of nitrogen and a solution of triphenylphosphine $(1.3 \mathrm{~g}, 0.005 \mathrm{~mol})$ in ethyl acetate $(20 \mathrm{ml})$ is added to the above solution at $-78^{\circ} \mathrm{C}$. The solution is allowed to reach room temperature and after $30 \mathrm{~min} 1 \mathrm{a}$ is extracted with distilled water $(3 \times 10 \mathrm{ml})$. The aqueous solution is titrated enzymatically using Gabase as described ${ }^{5}$. The concentration of $1 \mathrm{a}$ is determined as 0.23 molar. Pure 1a can be recovered by distillation; yield: $0.612 \mathrm{~g}(60 \%)$; b.p. $90-92^{\circ} \mathrm{C} / 0.05$ torr (Ref. ${ }^{3}$, b.p. $90-91{ }^{\circ} \mathrm{C} / 0.05$ torr) 


$\begin{array}{llrr}\mathrm{C}_{4} \mathrm{H}_{6} \mathrm{O}_{3} & \text { calc. } & \mathrm{C} 47.06 & \mathrm{H} 5.92 \\ (102.1) & \text { found } & 47.40 & 5.80\end{array}$

I.R. and ${ }^{1} \mathrm{H}$-N.M.R. $\left(\mathrm{CDCl}_{3}\right)$ spectra were in accord with reported values ${ }^{5}$, whereas in $\mathrm{D}_{2} \mathrm{O}$ no trace of the aldehyde hydrogen could be found in the N.M.R. spectrum ${ }^{4}$.

\section{2,4-Dinitrophenylhydrazone of $1 \mathrm{a}$ :}

A solution of $1 \mathrm{a}(51 \mathrm{mg}, 0.5 \mathrm{mmol})$ in water $(2 \mathrm{ml})$ is treated with a solution of 2,4-dinitrophenylhydrazine $(0.1 \mathrm{~g})$ in acetic acid $(2 \mathrm{ml})$ and the precipitate is filtered off. An additional purification is achieved by treatment of the ethyl acetate solution of the formed phenylhydrazone with a solution of sodium hydrogen carbonate, in which the derivative is soluble. Precipitation with 1 normal hydrochloric acid and recrystallization from methanol affords an analytically pure sample; m.p. 202 $203^{\circ} \mathrm{C}$ (Ref.', m.p. $203^{\circ} \mathrm{C}$ ).

$\begin{array}{llrrr}\mathrm{C}_{10} \mathrm{H}_{10} \mathrm{~N}_{4} \mathrm{O}_{6} & \text { calc. } & \mathrm{C} 42.55 & \mathrm{H} 3.54 & \mathrm{~N} 19.85 \\ (186.2) & \text { found } & 42.25 & 3.60 & 20.00\end{array}$

${ }^{1}$ H-N.M.R. (DMSO- $\left.d_{6}\right): \delta=2.65(\mathrm{~m}, 4 \mathrm{H}) ; 7.90(\mathrm{~d}, 1 \mathrm{H}) ; 8.2(\mathrm{~m}, 1 \mathrm{H})$; $8.45(\mathrm{dd}, 1 \mathrm{H}) ; 8.85 \mathrm{ppm}(\mathrm{d}, 1 \mathrm{H})$.

\section{Methyl 4-Oxobutanoate:}

A 0.42 molar aqueous solution of $1 \mathrm{a}(20 \mathrm{ml}, 8.4 \mathrm{mmol})$ is liophylized $\left(-30^{\circ} \mathrm{C} / 0.005\right.$ torr, $\left.12 \mathrm{~h}\right)$, the resultant oil $(0.86 \mathrm{~g})$ is dissolved in dry methanol $(5 \mathrm{ml})$, and treated with excess ethereal diazomethane solution (19 ml of 0.45 molar solution, $8.55 \mathrm{mmol}$ ). Evaporation of the solvents leaves a colourless oil $(0.96 \mathrm{~g})$ which is distilled; yield: $0.82 \mathrm{~g}$ (84\%); b.p. $76-78^{\circ} \mathrm{C} / 15$ torr (Ref. ${ }^{10}$, b.p. $76.5-77^{\circ} \mathrm{C} / 15$ torr).

$\begin{array}{llrr}\mathrm{C}_{5} \mathrm{H}_{8} \mathrm{O}_{3} & \text { calc. } & \mathrm{C} 51.72 & \mathrm{H} 6.94 \\ (116.2) & \text { found } & 52.00 & 7.05\end{array}$

I.R. (neat): $v=1740,1720 \mathrm{~cm}^{-1}$.

${ }^{1}$ H-N.M.R. $\left(\mathrm{CDCl}_{3}\right) ; \delta=2.7(\mathrm{~m}, 4 \mathrm{H}) ; 3.70(\mathrm{~s}, 3 \mathrm{H}) ; 9.70 \mathrm{ppm}(\mathrm{s}, 1 \mathrm{H})$.

The 2,4-dinitrophenylhydrazone is prepared as described above; m.p. $131-133^{\circ} \mathrm{C}\left(\operatorname{Ref} .^{10}\right.$, m.p. $\left.133-133.5^{\circ} \mathrm{C}\right)$.

'H-N.M.R. (DMSO- $\left.d_{6}\right): \delta=2.65(\mathrm{~m}, 4 \mathrm{H}) ; 3.70(\mathrm{~s}, 3 \mathrm{H}) ; 7.70(\mathrm{~d}, 1 \mathrm{H})$; $8.1(\mathrm{~m}, 1 \mathrm{H}) ; 8.30(\mathrm{dd}, 1 \mathrm{H}) ; 8.75 \mathrm{ppm}(\mathrm{d}, 1 \mathrm{H})$.

\section{Ethyl 4,4-Diethoxybutanoate:}

A 0.42 molar aqueous solution of $1 \mathrm{a}(6 \mathrm{ml}, 2.5 \mathrm{mmol})$ is treated as de scribed above. The resultant colourless oil is dissolved in dry ethanol $(5 \mathrm{ml})$ and treated with hydrogen chloride gas at room temperature. The solvent is evaporated under a stream of nitrogen at reduced pressure to leave a colourless residue consisting of equimolar amounts of ethyl 4,4-diethoxybutanoate and the semi-acetal of the ethyl ester of 1a (either open or cyclic form) according to the 'H-N.M.R. spectrum of a $\mathrm{CDCl}_{3}$ solution. Addition of $\mathrm{D}_{2} \mathrm{O}$ to this solution results in the appearance of a signal for an aldehydic hydrogen atom, probably arising from the facile hydrolysis of the cyclic form ${ }^{3}$.

${ }^{1}$ H-N.M.R. $\left(\mathrm{CDCl}_{3} / \mathrm{D}_{2} \mathrm{O}\right): \delta=1.25(\mathrm{t}) ; 1.95(\mathrm{~m}) ; 2.3-2.8(\mathrm{~m}) ; 3.6(\mathrm{~m})$; $4.20(\mathrm{q}) ; 4.60(\mathrm{t}) ; 5.55 \mathrm{ppm}(\mathrm{m})$

We thank Ministero della Pubblica Istruzione for financial support.

Received: September 23, 1982 (Revised form: November 16, 1982)

\footnotetext{
' E. Roberts, R. Hammerschlag, in: Basic Neurochemistry, R. W. Albers, G. J. Siegel, R. Katzman, B. W. Agranoff, Eds., Little Brown and Co., Boston, 1972, p. 131-165.

2 H. Laborit, in: Progress in Neurobiology Vol. 1, Part 4, G. A. Kerkut, J. W. Phillis, Eds., Pergamon Press, Oxford, 1973, p. 255 274.

3 C. G. Wermuth, J. Org. Chem. 44, 2406 (1979).

4 See, e.g. N. M. Tsybina, T. V. Protopopova, S. G. Rozenberg, A. I. Talygina, A. P. Skoldinov, Zh. Org. Khim. 7, 253 (1971); C. A. 74, 124652 (1971).

5 E. Santaniello, A. Manzocchi, Analyt. Biochem. 108, 190 (1980).

6 P. Yates, E. G. Lewards, P. H. McCabe, Can. J. Chem. 50, 1548 (1972).

7 A. Barco, S. Benetti, G. P. Pollini, R. Taddia, Org. Prep. Proc. Int. 6, 217 (1974).
}

${ }^{8}$ See, e.g. M. E. Jung, K. Shishido, H. L. Davis, J. Org. Chem. 47, 891 (1982).

9 H. Kondo, H. Suzuki, Ber. Dtsch. Chem. Ges. 69, 2459 (1936).

10 W. F. Gresham, R. E. Brooks, U. S. Patent 2497303 (1950): C. A. 44, 4492 (1950). 